\title{
Historical Legacies and Foreign Direct Investment in Bosnia and Herzegovina
}

Joel I. Deichmann *

Abstract:

This paper examines the origins of foreign direct investment (FDI) in Bosnia and Herzegovina (BiH) with special reference to historical legacies. BiH is a very interesting case because of its position on the frontier of Europe, a region with a rich cultural history marked by alternating periods of coexistence and violence. Because the country has spent time under the Ottoman, Austro-Hungarian, and Yugoslav flags, particular attention is paid to the role of history in impacting inflows of FDI. Five models are specified using various dependent variables to measure FDI, and all uphold the importance of historical legacies and cultural proximity. Equally interesting is the absence of significance among traditional gravity variables in this unique investment landscape. Policy implications include the need for government to assist firms in overcoming concern about instability, corruption, and a complex permitting process. As little has been published on FDI in BiH, future research suggestions are presented.

Keywords: foreign direct investment, origin effects, Bosnia and Herzegovina

JEL: C50, E01, F15, F49, 052

DOI: 10.2478/v10033-012-0001-y

\section{Introduction}

Foreign Direct Investment (FDI) is generally considered to be an engine for economic growth (Balasubramanyam, Salisu, and Sapsford 1999; Bevin and Estrin 2004; Demekas, Horváth, and Ribakova 2007), and as such it is pursued actively by government agencies such as FIPA, the Foreign Investment Promotion Agency of Bosnia and Herzegovina (Mustafic-Cokoja 2010). FDI brings advantages to the host country, such as technology transfer, skill diffusion, and income effects (Balasubramanyam et al. 1999), all of which have especially important implications for Bosnia and Herzegovina $(\mathrm{BiH})$ given its transitional status. Although a Stabilization and Association Agreement was signed with the European Union (EU) on 16 June 2008, BiH remains one of Europe's poorest countries, and thanks in part to its complex political structures, is generally considered to be at best a distant candidate for EU accession (Economist, 2011).
What makes BiH remarkable as a case for studying FDI inflows is its historical political and cultural affiliation with multiple powerful entities. This young state represents a unique geographic context as a successor region of the Ottoman and Austro-Hungarian Empires, as well as Yugoslavia. It is plausible that cultural linkages developed through these historical associations have led to a considerable portion of BiH's inward investment stock across present-day borders. Much work has been done to analyze FDI in transition economies of Europe, but most of these studies omit $\mathrm{BiH}$, in large part due to a lack of FDI until recently. Here, we focus on $\mathrm{BiH}$ alone because as Bevin and Estrin (2004, 780) convincingly

\footnotetext{
* Joel I. Deichmann

Global Studies Department

Bentley University

E-mail: jdeichmann@bentley.edu
} 
argue, in the former Yugoslavia, "conditions make (countries) special cases... they require country-specific explanations."

With regard to the transformational recession that has characterized the region of Central and Eastern Europe since the fall of the Iron Curtain and the demise of the former Yugoslavia, BiH finds itself in the "most miserable situation" (Koyama 2008, 138), largely due to its central position in the recent Balkan wars. Income levels remain considerably lower in SEE (Southeastern Europe) than in Central Europe and the Balkans, and investment inflows have generally been sluggish with the notable exception of Croatia, which itself has attracted more than half of the FDI stock in the Western Balkans (EBRD 2011). However, $\mathrm{BiH}$ and the broader region will likely gain relative attractiveness for some industries as conditions continue to stabilize, especially because the most attractive assets in Central Europe have already been sold, and wages there have increased (Kekic 2005).

\subsection{Overview of FDI in Bosnia- Herzegovina}

In attracting FDI, Bosnia and Herzegovina lags behind most states in the region, especially those countries that participated in the 2004 and 2007 EU expansions. Among twenty transition economies of Europe as of the end of 2009 , BiH ranks sixteenth with $€ 5.6$ billion, ahead of only Montenegro, Macedonia, Albania, and Moldova (calculations by Hunya 2010,24). However, in terms of stock per capita, $\mathrm{BiH}$ has attracted $€ 1500$, more than Russia, Ukraine, Moldova, or Belarus. Like most transition states, FDI in BiH peaked in 2007 (with $€ 1.517$ billion), and has since struggled to attract the attention of foreign firms, which are facing very difficult economic times (Vogel 2011).

Why has BiH been unable to attract large amounts of foreign capital, even long before the global economic crisis? According to a report by Business Monitor International (2010) the country continues to be plagued by weaknesses in the business environment, an uncompetitive tendering process, and the inefficiencies caused by the divided structure of the country and its bureaucracy. The consultants conclude that "this confused and dense bureaucracy presents further obstacles to the smooth running of a project and contributes to Bosnia's poor overall score of 40 out of 100 in BMI's Infrastructure Business Environment Ratings". These assertions are corroborated in The Economist (2011), which bemoans the complexity of BiH's government, headed by a "six-pack" of leaders from three distinct geographical entities.

In order to overcome the aforementioned disadvantages and facilitate FDI, BiH's Foreign Investment Promotion Agency (FIPA) was established in 1998. The agency also publishes data on investment inflows to the country since 1994. These data are obtained from the Bosnian Central Bank and by contacting investors themselves. Bandelj $(2010,487)$ points out that "professionalizing FDI by establishing a state FDI agency... show(s) the commitment of post socialist governments to FDI and will facilitate FDI transactions". FIPA serves three government entities: the Federation of Bosnia and Herzegovina, the Republika Srpska, and the small district of Brčko. Dika Mustafic-Cokoja (2010), Senior Advisor at FIPA, encourages investors by highlighting the advantages of the country's location at the crossroads of east and west, as well as low labor costs, inexpensive privatization deals, tax holidays, an investment support fund, and free trade with EU member states by virtue of the association agreement that was signed by Bosnia and Herzegovina in 2008. Importantly, such agencies confirm a commitment on the part of host governments to facilitating FDI, and an embrace of FDI as an engine for growth.

Table 1 shows the annual inflows of FDI to $\mathrm{BiH}$ from 2001-2009 in million Euros. By 2001, the total FDI stock had reached $10.2 \%$ of GDP (Hunya 2002, 11), about $\$ 125$ per capita. Since that time FDI inflows increased steadily until the financial crisis began in 2007, at which point FDI inflows to $\mathrm{BiH}$, like elsewhere, dropped off precipitously.

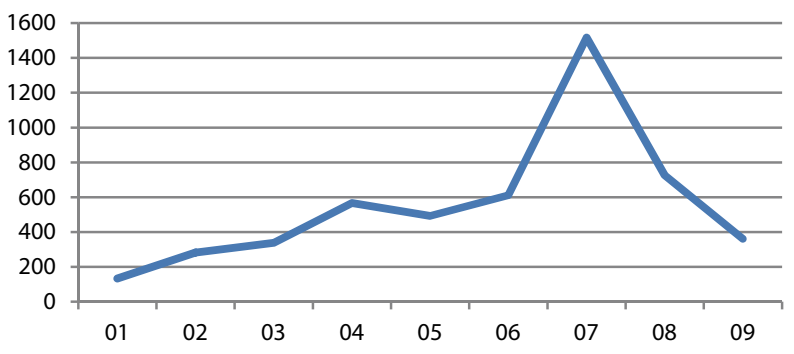

Figure 1: Annual Inflows of FDI into Bosnia and Herzegovina (Source: Hunya 2010)

Table 1 summarizes the leading origins of $\mathrm{FDI}$ in $\mathrm{BiH}$, as measured in thousands of Euros and in number of transactions. Both measures are deemed important because the value of investment represents its potential impact to the host economy, while the number of 
transactions is important because it signifies the number of firms that made the decision to invest in $\mathrm{BiH}$.

\begin{tabular}{|c|c|c|c|}
\hline & Country & $€ \mathrm{mil}$ & $\#$ \\
\hline 1. & Austria & 963 & 56 \\
\hline 2. & Serbia & 881 & 67 \\
\hline 3. & Croatia & 692 & 115 \\
\hline 4. & Slovenia & 547 & 78 \\
\hline 5. & Russia & 468 & 5 \\
\hline 6. & Germany & 286 & 35 \\
\hline 7. & Switzerland & 265 & 19 \\
\hline 8. & Lithuania & 256 & 3 \\
\hline 9. & Netherlands & 145 & 19 \\
\hline 10. & Turkey & 131 & 7 \\
\hline 11. & Italy & 120 & 45 \\
\hline 12. & Luxembourg & 83 & 5 \\
\hline 13. & United States & 55 & 16 \\
\hline 14. & UAE & 51 & 2 \\
\hline 15. & France & 49 & 4 \\
\hline 16. & Saudi Arabia & 48 & 5 \\
\hline 17. & Denmark & 36 & 9 \\
\hline 18. & Virgin Islands & 23 & 2 \\
\hline 19. & Cayman Islands & 22 & 1 \\
\hline 20. & United Kingdom & 22 & 11 \\
\hline 21. & Belgium & 21 & 1 \\
\hline 22. & Liechtenstein & 21 & 2 \\
\hline 23. & Kuwait & 20 & 5 \\
\hline 24. & Cyprus & 20 & 8 \\
\hline 25. & Sweden & 13 & 2 \\
\hline 26. & Bulgaria & 11 & 1 \\
\hline 27. & Poland & 9 & 1 \\
\hline 28. & Slovakia & 7 & 2 \\
\hline 29. & Montenegro & 7 & 3 \\
\hline 30. & Hungary & 7 & 4 \\
\hline 31. & Egypt & 5 & 1 \\
\hline 32. & Czech Republic & 4 & 3 \\
\hline 33. & Malaysia & 4 & 3 \\
\hline 34. & Norway & 3 & 2 \\
\hline 35. & China & 2 & 1 \\
\hline 36. & Spain & 1 & 2 \\
\hline 37. & Australia & 1 & 1 \\
\hline 38. & Guinea & 1 & 1 \\
\hline 39. & Tunisia & 1 & 1 \\
\hline
\end{tabular}

Data Sources: Central Bank of Bosnia and Herzegovina ( $€$ values, converted by author from KM), FIPA (\#). Note: transaction numbers ("\#”) are estimates only.

Table 1: Leading Origins of FDI in Bosnia and Herzegovina, 1994-2010

BiH's investment picture is dominated by European countries-in fact, the twelve leading origins of FDI are from Europe, followed by the United States and UAE. Three of the top four home countries were constituent regions of the former Yugoslavia. Intuitively, a glance at Table 1 suggests that gravity forces are likely at work. In other words, it is reasonable to expect that FDI is facilitated by geographical proximity, although most of the leading origins are not among the world's largest economies (note that the USA is \#13, Germany is \#6, and China, Japan, and India are absent from the rankings). The goal of the present research is to determine the explanatory variables governing the patterns presented in Table 1.

This paper is organized as follows. Following Section 1 , the relevant literature is reviewed in Section 2, followed by an overview of hypotheses in Section 3. Section 4 presents the data and methodology. The five models are analyzed in Section 5, along with a discussion of limitations and suggestions for policy and future study. Finally, Section 6 offers conclusions.

\section{Literature}

John Dunning (1980) set forth his pioneering "eclectic" framework for explaining the locational determinants of the origins and destinations of foreign direct investment, and subsequently (1998) reaffirmed the importance of place-specific advantages as facilitators of firms seeking resources, markets, efficiency, and/or strategic assets abroad. The first pillar of Dunning's "O-L-I" (ownership- location- internalization) approach establishes the precedent for the present study. Ownership advantages are enabling characteristics specific to home countries, and are also referred to as "origin-effects". Rodrígues-Pose and Crescenzi (2008) forcefully criticize Friedman's (2005) metaphor of a "Flat World", making the case for an enduring role of "mountains" that should not be overlooked in what has become a flourishing literature on economic geography with substantial reference to FDI. The case for the present study is made on the basis of interrogating findings from existing papers. Keeping existing contributions in mind, a manuscript by Grosse and Trevino (1996) offers the first such empirical study published on origin effects (of FDI in the USA), and provides a basic template to be replicated here in the context of $\mathrm{BiH}$.

In her analysis of FDI in Europe's transition economies, Bandelj (2002) introduces a relational approach that focuses on institutional, political, economic, and cultural connections as channels for transactions. She argues that such ties are particularly important in conditions of high risk. Although the only country from the Western Balkans that she considers is Croatia due to instability and incomplete data in this early (2002) paper, one might expect her findings to be applicable to the rest of South 
East Europe with the return of stability and acceleration of FDI one decade later.

Hunya (2002) provides an insightful commentary on South East Europe using WiiW data through 2001, observing that the global decline of FDI did not dramatically impact the region. Hunya laments that during the early 1990s, when the region needed FDI the most, its economic and political situation caused most investors to stay away, except for projects that yielded rapid returns. He further observes that beginning in 1997, with evidence of stability and progress in transformation, many countries in the region began to attract noteworthy levels of FDI. Even during this period, however, the complexity of administrative rules, lack of transparency, and excessive perceived risk crippled the region's ability to attract satisfactory FDI, a finding echoed by others (Brada, Kutan, and Yigit, 2006). For all of the reasons raised by Hunya, flows into $\mathrm{BiH}$ remained negligible until the late 1990s. The WiiW dataset continues to be a useful source of information on FDI flows, and Hunya (2010) provides regular discussions as updates are released.

Extending this rather pessimistic appraisal of the Balkan FDI scene is an inquiry by Bitzenis (2004) into the case of Bulgaria. Bitzenis examines the sub-national distribution of FDI according to the leading origins: Turkey, Russia, Greece, Germany, and Cyprus. He employs survey questionnaires to obtain answers on the importance of historical ties, common religion, and cultural closeness. This project is particularly instructive for the present study because the surveys permit the author to demonstrate a deep understanding of historical inertia and cultural proximity. Counter to his expectations, Bitzenis finds that in most investment cases in Bulgaria, historical links do not significantly affect the decision to invest, and his examination of the role of culture is inconclusive.

Bevin and Estrin (2004) offer one of the most comprehensive early analyses of FDI into European transition economies. While countries from the former Yugoslavia (with the exception of Slovenia) are excluded from their dataset, these authors set forth a useful framework to examine the role of GDP of origin and destination, distance, trade flows, and host country labor costs as well as a composite variable of risk factors. They find that FDI in transition countries is largely explained by gravity factors, including home country GDP and the distance of the home country to the host country. In addition, low labor costs and EU accession prospects are found to be significant facilitators of inward flows to the host countries.

Noting that only negligible FDI stock was present in CEE until the 1990s, and observing the dramatic upsurge thereafter, Brada et al. (2006) examine the enduring effects of economic transition and political instability in some countries, mainly those in the Balkans. Specifically, they point out that in addition to the aspect of political instability that captures uncertainty about whether democratic reform will continue, Balkan countries were hampered by investors' perceived risk in the midst of actual or potential warfare. Using benchmarks, the authors predict inflows to Europe's transition countries and compare them with the actual FDI. It was not until 1999 when actual FDI in BiH surpassed the levels predicted by two equations of economic and political determinants. The authors attribute shortfalls from expected FDI inflows to the added risks caused by regional strife in $\mathrm{BiH}$ and its neighbors.

Demekas et al. (2007) demonstrate the practicality of gravity approaches for understanding the distribution of FDI in transition economies of Central and Eastern Europe (CEE), highlighting the importance of government policies. They find that unit labor costs, corporate tax burden, infrastructure, and foreign exchange and trade regime all impact the relative attractiveness of host countries, and they estimate the total FDI that can be achieved with careful policy. Among the countries under investigation, Bosnia and Herzegovina exhibits the largest gap between actual and potential FDI (83 percent). In other words, due to failed government policies, actual FDI in the country is only 17 percent of its potential. This finding underscores the need to better understand the investment situation in Bosnia and Herzegovina in particular.

Koyama (2008) offers an extensive volume that analyzes various aspects of transition in Central and Eastern European Countries using data from the Vienna Institute for International Economic Studies ("WiiW", see Hunya 2010), which in turn are collected from respective national banks. In his chapter on Foreign Direct Investment in the region, he maintains that FDI in $\mathrm{BiH}$ remains stunted by high corruption levels and residual memories of conflict, resulting in FDI stock per capita of merely $\$ 435$ by 2004, surpassing only Serbia and Montenegro. However, he cites a recent upswing in FDI attributable to privatization deals. Because of data constraints, his analysis of $\mathrm{BiH}$ is broadened to regional groupings, and the country is absent from most of the 
data tables. However, Koyoma $(2008,202)$ does refer to projects that show "strong economic connection" between $\mathrm{BiH}$ and other republics of the former Yugoslavia. As evidence, he shows that within the Balkans, BiH participates in the highest percentage of intra-regional trade since 1995.

Bandelj (2010) provides an excellent analysis of EU integration and legacies as factors raising FDI inflows into the ten CEE countries that joined the European Union in 2004 and 2007. In particular, her articulation of postsocialist legacies is relevant to the consideration here of the linkages that developed throughout the former Yugoslavia. She also finds evidence that EU accession has both direct and indirect advantages for investors. She then goes on to discuss the temporary handicap to foreign firms introduced in Slovakia under Mečiar's corrupt and repressive regime that favored political cronies, a similar phenomenon to that which at times has been at work in $\mathrm{BiH}$.

\section{Hypotheses}

Based on the aforementioned literature and on related plausible expectations, the seven hypotheses are set forth. It is expected that the origins of $\mathrm{FDI}$ in $\mathrm{BiH}$ can be explained in large part by a shared history of political union, origin country market size and market strength, EU membership, geographic and cultural distance, and bilateral trade flows.

\section{H1 History of Political Union (POL)}

Firms from countries that have been formally aligned with $\mathrm{BiH}$ are more likely to do business there. The rationale for this expectation is that $\mathrm{BiH}$ did not begin with a "clean slate" on November 21, 1995 when the Dayton Accords were signed. Like elsewhere in transition economies (Bandelj 2002), embedded networks in various forms are likely to channel economic transactions such as investment. Moreover, Murat and Pistoresi (2009) demonstrate that migration facilitates investment, and centuries of human movement throughout the region are enabled within territorial regimes, although their borders have shifted.

The nascent federal democratic republic of $\mathrm{BiH}$ has a long history as part of other empires and nation-states. For four centuries (1463-1878), the region was dominated by the Ottoman Empire, and was later ceded to AustroHungary, with which it remained formally affiliated until
1918. From 1918-1992, BiH was predominantly affiliated with various forms of the Yugoslav state, and following Bandelj (2010) socialist legacies are likely to remain, connecting it to the other former republics. In particular and most recently, BiH's centralized location within Yugoslavia and its natural resources served as advantages for developing military and other manufacturing industries that were distributed to portions of Yugoslavia that now represent separate states.

\section{H2 Market Size (GDP)}

Gravity models predict that the interaction between two bodies is positively related to the size of those bodies. With the bodies in question here representing Bosnia and its FDI origins, and, following Kleinert and Toubal (2010) who define interaction as FDI flows, it is expected that FDI will be greater from countries with larger economies, measured by Gross Domestic Product. Evidence of GDP's role was documented by Bevan and Estrin (2004) in the context of other European transition economies, and Botrić and Škuflić (2006) report its significant effect in South East Europe. The testing of $\mathrm{H} 2$ will either extend or refute the role of economic mass as a determinant of FDI in $\mathrm{BiH}$.

\section{H3 Market Strength (GNIPC)}

Gross National Income per capita (GNIPC) is a measure of relative economic strength. It is expected that firms from wealthier economies as measured by GNIPC will be more inclined to invest in $\mathrm{BiH}$ due to an access to venture capital at home. The variable can also be viewed as a surrogate for wages, which could be a reason for firms to pursue labor-intensive production outside their own borders.

\section{H4a EU membership (EU)}

Bevin and Estrin (2004) note that announcements about EU accession help attract FDI inflows into European transition countries, and Brada et al. $(2006,669)$ argue that many investments are made "with a view to (host countries') entry into the EU". Similarly, Bandelj (2010) finds that impending EU membership reduces perceived risks, and therefore facilitates cross-border FDI among transition economies. Although its membership is not yet "impeding", since $1998 \mathrm{BiH}$ has participated in the EU Stabilization and Association Process (SAP), which grants 
the Western Balkans access to the European Union market for almost all products. The SAP is in place for Albania, Croatia, the former Yugoslav Republic of Macedonia, and Montenegro, while Bosnia and Herzegovina has made interim agreements on trade and trade-related matters.

\section{H4b EU Membership post-2007}

EU membership will be relatively less important as an FDI facilitator since 2007, when firms from the leading European origins of FDI became preoccupied with more immediate challenges related to the financial collapse. FDI flows have declined in many regions since 2007, but the European Union is expected to be particularly hardhit as a source of investment (Hunya 2010), beginning to recover only in 2011 (Vogel 2011).

\section{H5 Geographic Distance (GEOG)}

Gravity models predict that the distance between two bodies will obstruct interaction between them, and this is found to be the case by Bevan and Estrin (2004) as a location choice determinant in European transition economies, measured as the distance between the capital cities of country $i$ and country $j$. Bitzenis (2004) corroborates this finding with Greek MNEs in Bulgaria. Although these authors do not examine $\mathrm{BiH}$ in their work, the same "distance decay" effect can be expected to hold true in this case. Appreciation for the friction of geographic distance is making a revival in the broader economic geography literature (Rodrígues-Pose and Crescenzi 2008), and for FDI models specifically (Kleinert and Toubal 2010), where distance is widely accepted as increasing fixed costs of operating between two countries.

\section{H6 Cultural Distance (CULT)}

Following Bandelj (2002), cultural ties are expected to facilitate FDI. However, these are not the same facilitators as shared political authority as articulated in $\mathrm{H} 1$. In this case, cultural distance is measured by a language proxy index ranging from 1-5, based on the degree of differences between origin country language and alphabet, and those of BiH. For example, Croats and Serbs $($ "1") use a mutually intelligible tongue and share alphabets (Latin and Cyrillic, respectively); Russians ("2") use a different Slavonic tongue and the Cyrillic alphabet.
Because English and German are widely spoken in $\mathrm{BiH}$, all native English and German speaking states are assigned " 2 ", and so on, whereas China, Japan, and are assigned a " 5 " for the extreme end of the cultural continuum. Given the historical importance of Islam in $\mathrm{BiH}$, on a case-bycase basis scores for countries sharing the Islamic faith are reduced by one in order to capture this cultural tie (for example, Turkey and Saudi Arabia), both of which score a " 4 " rather than a " 5 ". 1

\section{H7 FDI will be positively related to trade flows (InTRADE)}

Earlier evidence of trade's role in facilitating FDI in transition economies is presented by Bevin and Estrin (2004), albeit in a lagged model. Blonigen (2001) finds evidence of both substitutional and complementarity effects of trade. Others argue that the two are modes are alternative forms of international operation, and that no theoretical basis exists for them to be related. (Meredith and Maki 1992) find evidence that they are mutually reinforcing. The World Trade Organization (1996) suggests that the relationship between FDI and trade is...

"more complex than is suggested by the traditional view that FDI and trade are alternative means of servicing a foreign market, and hence substitutes. FDI and the trade of home and host countries are, as has been noted, generally complementary. In this connection, liberal trade and investment policies boost FDI and strengthen the positive relationship between FDI and trade. In contrast, high tariffs, threats of contingent protection and financial or tax-based subsidies can create strong incentives to substitute investment for trade, including - in the case of countries with large domestic markets relative to their neighbours - for the diversion of investment by neighbouring firms into the protecting country".

Given these divergent points of view and a lack of concrete evident about the relationship, beyond the scope of this paper lies a more complete debate about the relationship between trade and FDI.

This analysis leaves out some conventional origin effects such as exchange rate change (Grosse and Trevino 1996), omitted because the $\mathrm{BiH}$ convertible mark (KM) is

\footnotetext{
${ }^{1}$ A full list of scores is available from the author.
} 
pegged to the Euro, in use by many of the leading investing countries. Other variables, including political countries that are most associated with the Ottoman and Austro-Hungarian Empires, and the former Yugoslavia. EU

\begin{tabular}{|c|c|c|c|c|c|}
\hline & $\begin{array}{c}\text { Model } 1 \\
\text { Coefficients }\end{array}$ & $\begin{array}{c}\text { Model } 2 \\
\text { Coefficients }\end{array}$ & $\begin{array}{c}\text { Model } 3 \\
\text { Coefficients }\end{array}$ & $\begin{array}{l}\text { Model } 4 \\
\text { Coefficients }\end{array}$ & $\begin{array}{c}\text { Model } 5 \\
\text { Coefficients }\end{array}$ \\
\hline $\begin{array}{c}\text { Independent } \\
\text { Variable } \downarrow\end{array}$ & $1994-2010$ & $1994-2010$ & $1994-2006$ & 2007-2010 & Transactions \\
\hline Constant (e) & 86.639 & 8.313 & 54.039 & 63.532 & 12.090 \\
\hline \multicolumn{6}{|l|}{$\ln (G D P)$} \\
\hline POL & $129.098^{a}$ & $216.973^{a}$ & $63.643^{a}$ & $76.802^{\mathrm{a}}$ & $19.556^{\mathrm{a}}$ \\
\hline \multicolumn{6}{|l|}{ GNIPC } \\
\hline EU & & & $3.356^{c}$ & & \\
\hline \multicolumn{6}{|l|}{ GEOG } \\
\hline CULT & $-19.173^{c}$ & $-28.182^{a}$ & $-12.086^{b}$ & $-13.840^{b}$ & $-2.589^{\mathrm{a}}$ \\
\hline In(TRADE) & $9.792^{c}$ & & & & \\
\hline$R^{2}$ & $.305^{c}$ & $.284^{\mathrm{a}}$ & $.250^{\mathrm{a}}$ & $.192^{b}$ & $.329^{\mathrm{a}}$ \\
\hline
\end{tabular}

${ }^{\text {a }}$ Statistically significant at the 0.001 level (two-tailed)

${ }^{b}$ Statistically significant at the 0.01 level (two-tailed)

cStatistically significant at the 0.05 level (two-tailed)

Table 2: Coefficients and Significance Levels of Variables in the Models

stability (Brada et al. 2006), and corruption measures in the home country, as examined by Deichmann (2010) are omitted in the interest of parsimony. Moreover, they are not expected to play a role in corporations' decisions to invest in $\mathrm{BiH}$.

\section{Data and Methodology}

The data for the dependent variables are acquired from the Central Bank of Bosnia and Herzegovina. Following Zademach and Rodríguez-Pose (2009), both the value of investment and the number of transactions are considered here in an effort to accurately capture the investment picture. The dependent variables represent mean values over the period under consideration (20002009), and are measured in millions of Euros. Where missing values are present, the means are used.

The approach employed is ordinary least squares (OLS) regression, roughly as applied by Gross and Trevino (1996) to examine Origins of FDI in the USA. With the exception of Model 1, following Botrić and Škuflić (2006), in order to allow for more degrees of freedom, the independent variables are added selectively. Two of the independent variables (GDP, GNIPC) are obtained from the World Bank, and are measured in millions of US\$ and in US\$, respectively. POL is a dummy variable for the is the number of years that an origin country held EU membership during the time period in question. For example, the Netherlands has the value of ten, Slovenia six, and Romania three. Distance is measured between economic centroids, improving upon Bevan and Estin's (2004) use of capital cities. For example, for Germany this is the distance between Sarajevo and Frankfurt rather than Berlin. Cultural distance is estimated on a scale of 1-5 based mainly on linguistic affinities. Adapted from Deichmann (2010), countries where Slavonic languages represent the mother tongue are given a score ranging from "1-2, depending on the level of similarity", with Japanese, Chinese, and Korean at the opposite end of the continuum with " 5 ". Because of the prominence of Islam and use of the Cyrillic alphabet in the Republika Srpska of $\mathrm{BiH}$, these language-based scores are lowered by one point to indicate cultural links to countries including Saudi Arabia and Russia, respectively. The trade variable, reported by Bosnia and Herzegovina's Federal Office of Statistics, is in millions of US\$. Finally, to correct for heteroscedasticity, logarithmic transformations are applied to the GDP and trade variables. Following Burger, Van Oort, and Linders (2009), to avoid bias, values equal to or less than zero are replaced with a small positive number, and in this case 0.1 is employed. This practice is 
in order because the goal is to understand FDI inflows, not the withdrawal of investment (negative values).

Table 2 reports the outputs of the five models. Model 1 offers an initial solution by entering all variables including trade for cumulative FDI through 2010. In the interest of efficiency, Model 2 follows a stepwise forward selection algorithm to explain the same variable. Model 3 uses the same selection process for all variables, but only through 2006 (prior to the global recession). Model 4: repeats the process for the next time period: 2007-2010. Finally, Model 5 allows the algorithm to specify the best explanatory variables, but using the number of transactions from 1994-2010 as the dependent variable, thereby interrogating findings on FDI values.

\section{Analysis}

Table 2 shows that a handful of variables performed well across all of the models, irrespective of specification and dependent FDI variable. As predicted, political legacy and cultural distance both play a role as origin-effects of FDI in Bosnia and Herzegovina. Evidence is abundant that firms from countries that once represented the Ottoman and Austro-Hungarian Empires, as well as the former Socialist Federal Republic of Yugoslavia, enjoy advantages that facilitate FDI across present-day borders. The value of trade (logarithmic transformation) is omitted from models subsequent to 1 , because of its high correlation with many of the dependent and independent variables (notably, its simple correlation with the dependent variables in Appendix C). Moreover, uncertainty remains as to whether trade and FDI are substitutes for one another (Meredith and Maki 1992), bringing to question whether trade itself should be considered a dependent variable in such models (see also World Trade Organization 1996). While it was worthwhile to include the variable in Model 1, because of this ambiguity and its non-significance, it is removed from this exercise to allow for further debate elsewhere.

Model 2 yields determinants of cumulative value through 2010. With the removal of trade, the significant variables remain political legacy and cultural distance, with the model's tolerance improving to .758 and the variance inflation factor (VIF) at the satisfactory level of only 1.319. As predicted, political legacy shows a positive valence, while FDI is negatively related to distance. Tscores are 4.928 and -3.728 , respectively, and both are significant at the $\mathrm{p}=.000$ level. Because of the complexity of operating in $\mathrm{BiH}$, an investment environment that lacks transparency, the advantage of cultural knowledge is enormous. FIPA's senior advisor Dika Mustafic-Cokoja (2010) clarifies this observation with her explanation that companies from "neighboring countries are informed about safety in Bosnia".

Model 3 examines only FDI stock through 2006, but yields similar results. Again, political legacy and cultural distance are both significant factors, but EU membership also enters this equation with $p=.04$ that the relationship is due to chance. A glance at the model's marginal effects suggests that every year of EU membership for the origin country leads to $€ 3,356,000$ of additional FDI, lending credence to the assertion that EU associate membership is indeed important. Finally, it is worth noting that the model's tolerance and VIF show further convergence toward the value of 1.0 and therefore no sign of problematic multi-collinearity in the model.

The dependent variable in Model 4 is the total FDI flow from 2007-2010, approximating the years of global recession. During this time period, EU membership drops out of our explanation, suggesting that leading firms from EU countries were unsurprisingly preoccupied with challenges outside of $\mathrm{BiH}$, corroborating observations from Hunya (2010) and EBRD (2011) elsewhere in the region.

Following Zademach and Rodríguez-Pose (2009), Model 5 is intended to either confirm or refute the findings of Models 1-4 by replacing the dependent variable of FDI value with the number of investment decisions. The rationale for using "transactions" as a dependent variable is that each investment represents a location decision by foreign executives, irrespective of their firm's size. Remarkably, the model yields an identical set of significant variables to those yielded by Model 2; again, political affiliations and cultural distance are key players in the origins of FDI to the nascent federal democratic republic.

Overall, the models performed well, with satisfactorily high tolerances and low VIFs, suggesting a reasonable level of parsimony. The $R^{2}$ scores were relatively low (.192.329), but nonetheless significant. What is surprising in these models is the non-role of traditional gravity variables, specifically origin country size and geographic distance. Less than two decades after the demise of Yugoslavia and the region's debilitating war, the situation of Bosnia and Herzegovina remains unique in that traditional explanations of FDI that have been confirmed in many other contexts (Demekas et al. 2007) do not appear to apply. Of course, the role of these gravity 
variables was likely confounded by the global economic crises that began in 2007, especially when EU countries in southern Europe demanded the attention of larger and more stable EU members, from which investors might have otherwise been looking outside for opportunities to attain new markets, resources, or efficiencies.

This paper yields several policy implications. First, the government of $\mathrm{BiH}$, led by its investment agency FIPA, needs to continue its assertive external public relations campaign to attract investors. They have gone a long way with their new high-profile headquarters in the Avaz Twist Tower. As the Economist (2011) report to its business-oriented readership, many problems remain for $\mathrm{BiH}$, including an enduring association with the destructive war, a lack of central authority in the country, fifteen months leading into 2012 without a proper national government, and problems with transparency and permitting. Visiting 500 foreign companies in $\mathrm{BiH}_{\text {, }}$ FIPA documented complaints from "most" about administration and corruption (Mustafic-Cokoja 2010). Ms. Cokoja adds that most potential investors ask about corruption in the country and they "need to be reassured".

As articulated by Bitzenis (2004) in Bulgaria, such factors contribute to a negative reputation and deter investors. What can help the country is the government's attention to such investment climate ills, and a rapid pursuit of EU membership, which will take the respective cooperation of the sometimes obstructionist parties in the Republika Srpska and the Bosniak-Croat Federation. FDI is not an end in itself, but it has enormous potential in promoting convergence with the rest of Europe (Balasubramanyam et al. 1999, Ribakova 2007) through wage increases and technology transfers, and it should continue to be a high priority for Bosnia's new leadership.

It is reasonable to acknowledge some methodological limitations of this work, and to point to further work that needs to be done on the topic. While the paper succeeds at its goals of identifying overarching trends-the origin effects of agglomeration, historical connections, and EU membership, these general tendencies do not hold true in every investment case. For example the Central Bank lists one investment project from China and two from the United Arab Emirates. Neither of these countries shares historical ties or cultural proximity with $\mathrm{BiH}$, nor are they EU members. In other words, while these findings claim that such historical and cultural factors are important, the econometric approach overlooks the stories of these firms. Given the limited scope of the present paper, by necessity such firm-specific considerations are passed over at the expense of grasping the big picture, or "the forest for the trees". To better understand such investments, a case study approach would be in order. Moreover, many of the determinants under consideration, including gravity variables, could be usefully re-examined at the sub-national scale, which would similarly require a case study approach, or better data from the constituent agencies of the $\mathrm{BiH}$ government.

\section{Conclusions}

This paper has examined the origins of FDI into Bosnia and Herzegovina, paying special attention to historical and cultural factors. Evidence is unveiled that both factors, as well as EU membership, play a strong role in facilitating FDI to Bosnia and Herzegovina. Over the past five centuries, $\mathrm{BiH}$ represented a portion of the Ottoman and Austro-Hungarian Empires, and later the Socialist Federal Republic of Yugoslavia, and there is evidence that this shared history has facilitated the establishment or reopening of business relationships across present-day borders. In the period of 1994-2006 following the war, companies from European Union members enjoyed an advantage in FDI, thanks also to bilateral agreements between those countries and $\mathrm{BiH}$.

Finally, among the most interesting results of this study is the absence of evidence for traditional gravity variables as FDI determinants, including market size and geographical distance, although proximity is admittedly captured partly by the political legacies variable. This observation is attributed to the unique investment environment of $\mathrm{BiH}$. Vis-à-vis its neighbors, $\mathrm{BiH}$ had a late start attracting FDI (Hunya 2002), but as indicated by Mustafic-Cokoja (2010), investors from familiar countries posses the necessary local knowledge to operate in this challenging and unique environment. While bilateral trade flows are related to FDI, it is unclear from this analysis whether they facilitate FDI or compete with it. ㄷ.

\section{References}

Balasubramanyam' V.N, M. Salisu' David Sapsford 1999. Foreign Direct Investment as an Engine of Growth. Journal of International Trade and Economic Development. 8 (1) 27-40.

Bandelj, Nina. 2002. How EU Integration and Legacies Mattered for Foreign Direct Investment into Central and Eastern Europe. Europe-Asia Studies. 62 (3), 481-501. 
Bandelj, Nina. 2010. Embedded Economies: Social Relations as Determinants of Foreign Direct Investment in Central and Eastern Europe. Social Forces. 81 (2) 411-444.

Bevin, Alan A, and Saul Estrin. 2004: The Determinants of Foreign Direct Investment into European Transition Economies. Journal of Comparative Economics. 32, 775-787.

Bitzenis, Aristidis. 2004. Explanatory Variables for Low Western Investment in Bulgaria. Eastern European Economics. 42 (6), 5-38.

Blonigen, Bruce. 2005. A Review of the Empirical Literature on FDI Determinants. Atlantic Economic Journal. 33 (December), 383-403.

Bosnia and Herzegovina Federal Office of Statistics. 2010. Statistical Yearbook. http://www.fzs.ba/Eng/gode.htm, accessed 10 January 2011.

Botrić, Valerija, and Lorena Škuflić. 2006. Main Determinants of Foreign Direct Investment in the Southeast European Countries. Transition Studies Review. 13 (2), 359-377.

Brada, Josef C., Ali M. Kutan, and Taner M. Yigit. 2006. The Effects of Transition and Political Instability on Foreign Direct Investment Flows: Central Europe and the Balkans. Economics of Transition. 14 (4), 649-680.

Business Monitor International. 2010. Country Risk Analysis for Bosnia and Herzegovina (Q4). http://www.businessmonitor.com/, accessed 10 January 2011.

Deichmann, Joel I. 2010. Origin-Effects and Foreign Direct Investment in the Czech Republic: The Role of Government Promotion Abroad. Comparative Economic Studies 52, 249-272.

Demekas, Demekas G., Baláz Horváth, and Elina Ribakova. 2007. Foreign Direct Investment in European Transition Economies- The Role of Policies. Journal of Comparative Economics. 35, 369-386.

Dunning, J. 1980. Toward an Eclectic Theory of International Production: Some Empirical Tests, Journal of International Business Studies. 11: 9-31.

Economist. 2011. No more Brussels bluff: The European Union should get on with admitting the better-run countries from the western Balkans. June $2^{\text {nd }}$. Available at: http://www.economist.com/node/18774816, accessed 14 September.

European Commission 2011. Taxation and Customs Union (overview). http://ec.europa.eu/taxation_customs/customs/customs_duties/rules_o rigin/preferential/article_784_en.htm accessed 9 September 2011.

Dunning, J. H. 1998. Location and the multinational enterprise: A neglected factor? Journal of International Business Studies. 29 (1): 45-66.

EBRD (European Bank for Reconstruction and Development). 2011. Transition Report Crisis in Transition: The People's Perspective. Available at http://www.ebrd.com/pages/research/publications/flagships/transition. shtml, accessed 10 February 2012.

Friedman, Thomas. 2005. The World Is Flat: A Brief History of the TwentyFirst Century. New York: Farra, Straus, and Giroux.

Grosse, Robert, and Len Trevino. 1996. Foreign Direct Investment in the United States: An Analysis by Country of Origin. Journal of International Business Studies. 27 (1), 139- 155.

Hunya, Gábor. 2002. FDI in South-Eastern Europe in the Early 2000s. The Vienna Institute for International Economic Studies (WIIW). Available at: http://www.africacommitments.org/dataoecd/52/30/1940829.pdf, Accessed 10 October 2011.

Hunya, Gábor. 2010. Database on Foreign Direct Investment in Central, East and Southeast Europe, 2010: FDI in the CEECs Hit Hard by the Global Crisis. Vienna Institute for International Economic Studies. http://publications.wiiw.ac.at/files/pdf/FDI/fdi_may10_contents.pdf, downloaded 14 October 2011.
Isard, Walter. 1975. A simple Rationale for Gravity Model Type Behavior. Papers of the Regional Science Association. 35, 25-30.

Janicki, Hubert, and Phanindra V. Wunnava 2004. Determinants of foreign direct investment: empirical evidence from EU accession candidates. Applied Economics. 36 (5), 505-509.

Kekic, Laza. 2005. Foreign Direct Investment in the Balkans: Recent Trends and Prospects. Journal of Southeast Europe and Black Sea Studies 5 (2), 171-190.

Kleinert, Jőrn, and Farid Toubal. 2010. Gravity for FDI. Review of International Economics. 18 (1), 1-13.

Koyama. Yoji. 2008. Transition, European Integration and Foreign Direct Investment in Central and Eastern European Countries. Niigata:

Shinkousoku Printing Co., Ltd.

Meredith, L. and D. Maki. 1992. The United States Export and Foreign Direct Investment Linkage in Canadian Manufacturing Industries. Journal of International Business Studies. 24: 73-88.

Mustafic-Cokoja, Dika. 2010. Interview with Senior Advisor of Foreign Investment Promotion Agency (FIPA), Sarajevo, Bosnia and Herzegovina. November 5.

O'hUallacháin, Breandán and Nigel Reid. 1992. Source country differences in the spatial distribution of foreign direct investment in the United States. The Professional Geographer. 44: 272-285.

Rodríguez-Pose, Andrés, and Riccardo Crescenzi. 2008. Mountains in a flat world: why proximity still matters for the location of economic activity. Cambridge Journal of Regions, Economy and Society. 1, 371-388.

Vogel, Toby. 2011. Global FDI rebounding after three-year decline. EuropeanVoice On-Line. www.europeanvoice.com. Accessed 28 July.

World Trade Organization. 1996. Trade and Foreign Direct Investment. PRESS $/ 57$

9 October 1996. Available at:

http://www.wto.org/english/news_e/pres96_e/pr057_e.htm, Accessed 17 February 2012.

Zademach, Hans-Martin, Andrés Rodríguez-Pose. 2009. Cross-Border M\&As and the Changing Economic Geography of Europe. European Planning Studies, 17 (5) 765 - 789 


\section{Appendix A: Countries in the dataset}

Afghanistan
Albania
Algeria
Andorra
Angola
Antigua and Barbuda
Argentina
Armenia
Australia
Austria
Azerbaijan
Bahamas, The
Bahrain
Bangladesh
Barbados
Belarus
Belgium
Belize
Benin
Bhutan
Bolivia
Bosnia
Botswana
Brazil
Brunei
Bulgaria
Burkina Faso
Burma (Myanmar)
Burundi
Cambodia
Cameroon
Canada
Cape Verde
Central African Rep
Chad
Chile
China
Colombia
Comoros
Congo (Brazzaville)
Congo (Kinshasa)
Costa Rica
Cote d'Ivoire
Cuba
Cyprus
Denmark
Djibouti

Dominica
Dominican Republic
East Timor
Ecuador
Egypt
El Salvador
Equatorial Guinea
Eritrea
Estonia
Ethiopia
Fiji
Finland
France
Gabon
Gambia
Georgia
Germany
Ghana
Greece
Grenada
Guatemala
Guinea-Bissau
Guinea
Guyana
Haiti
Honduras
Hungary
Iceland
India
Indonesia
Iran
Iraq
Ireland
Israel
Italy
Jamaica
Japan
Kordan
Kazakhstan
Kenya
Kiribati
Latvia
Lebanon

\begin{tabular}{|c|c|}
\hline Lesotho & Saint Lucia \\
\hline Liberia & Saint Vincent \\
\hline Libya & Samoa \\
\hline Liechtenstein & San Marino \\
\hline Lithuania & Saudi Arabia \\
\hline Luxembourg & Senegal \\
\hline Macedonia & Serbia/Montenegro \\
\hline Madagascar & Seychelles \\
\hline Malawi & Sierra Leone \\
\hline Malaysia & Singapore \\
\hline Maldives & Slovakia \\
\hline Mali & Slovenia \\
\hline Malta & Solomon Islands \\
\hline Marshall Islands & Somalia \\
\hline Mauritania & South Africa \\
\hline Mauritius & Spain \\
\hline Mexico & Sri Lanka \\
\hline Micronesia & Sudan \\
\hline Moldova & Suriname \\
\hline Monaco & Swaziland \\
\hline Mongolia & Sweden \\
\hline Morocco & Switzerland \\
\hline Mozambique & Syria \\
\hline Namibia & Taiwan \\
\hline Nauru & Tajikistan \\
\hline Nepal & Tanzania \\
\hline Netherlands & Thailand \\
\hline New Zealand & Togo \\
\hline Nicaragua & Tonga \\
\hline Niger & Trinidad and Tobago \\
\hline Nigeria & Tunisia \\
\hline Norway & Turkey \\
\hline Oman & Turkmenistan \\
\hline Pakistan & Tuvalu \\
\hline Palau & Uganda \\
\hline Panama & Ukraine \\
\hline Papua New Guinea & United Arab Emirates \\
\hline Paraguay & United Kingdom \\
\hline Peru & United States \\
\hline Philippines & Uruguay \\
\hline Poland & Uzbekistan \\
\hline Portugal & Venezuela \\
\hline Puerto Rico & Vietnam \\
\hline Qatar & Yemen \\
\hline Romania & Zambia \\
\hline Russian Federation & Zimbabwe \\
\hline
\end{tabular}

Saint Kitts and Nevis 


\section{Appendix B: Descriptive Statistics}

\begin{tabular}{|c|c|c|c|c|c|}
\hline & $\mathbf{N}$ & Minimum & Maximum & Mean & Std. Deviation \\
\hline $94-2010$ & 190 & .1 & 963.00 & 25.5326 & 122.08973 \\
\hline $94-2006$ & 190 & .1 & 575.00 & 12.8432 & 63.09071 \\
\hline 07-2010 & 190 & .1 & 818.00 & 12.5168 & 72.38503 \\
\hline Transactions & 190 & .1 & 115.0 & 2.959 & 12.6028 \\
\hline InGDP & 190 & 4.4400 & 16.1600 & 9.702632 & 2.3378685 \\
\hline POL & 189 & 0 & 1 & .08 & .271 \\
\hline GNIPC & 190 & 114.0000 & 113999.3300 & 8192.531632 & 14432.46417 \\
\hline EU & 189 & 0 & 10 & 1.08 & 2.904 \\
\hline DIST & 189 & 170 & 18261 & 5866.29 & 4105.105 \\
\hline CULT & 190 & 1 & 5 & 4.13 & 1.148 \\
\hline InTRADE & 187 & 6 & 7.05 & .7925 & 2.46145 \\
\hline
\end{tabular}

\section{Appendix C: Correlation Matrix}

\begin{tabular}{|c|c|c|c|c|c|c|c|c|c|c|c|}
\hline & $\begin{array}{c}94- \\
2010\end{array}$ & $\begin{array}{c}94- \\
2006\end{array}$ & $\begin{array}{c}07- \\
2010\end{array}$ & Trans & InGDP & POL & GNIPC & EU & DIST & CULT & $\begin{array}{c}\text { Ln } \\
\text { TRADE }\end{array}$ \\
\hline $94-2010$ & 1 & .854 & .859 & .859 & .188 & .480 & .148 & .221 & -.257 & -.438 & .458 \\
\hline $94-2006$ & .854 & 1 & .489 & .854 & .207 & .427 & .200 & .300 & -.248 & -.400 & .442 \\
\hline 07-2010 & .859 & .489 & 1 & .651 & .124 & .395 & .045 & .109 & -.212 & -.360 & .380 \\
\hline Trans & .859 & .854 & .651 & 1 & .196 & .535 & .158 & .271 & -.271 & -.442 & .498 \\
\hline $\operatorname{lnGDP}$ & .188 & .207 & .124 & .196 & 1 & .138 & .302 & .379 & -.187 & -.386 & .499 \\
\hline POL & .480 & .427 & .395 & .535 & .138 & 1 & .036 & .313 & -.380 & -.489 & .561 \\
\hline GNIPC & .148 & .200 & .045 & .158 & .302 & .036 & 1 & .400 & -.279 & -.313 & .431 \\
\hline EU & .221 & .300 & .109 & .271 & .379 & .313 & .400 & 1 & -.421 & -.286 & .614 \\
\hline DIST & -.257 & -.248 & -.212 & -.271 & -.187 & -.380 & -.279 & -.421 & 1 & .374 & -.403 \\
\hline CULT & -.438 & -.400 & -.360 & -.442 & -.386 & -.489 & -.313 & -.286 & .374 & 1 & -.598 \\
\hline InTRADE & .458 & .442 & .380 & .498 & .499 & .561 & .431 & .614 & -.403 & -.598 & 1 \\
\hline
\end{tabular}

